\title{
Research on the Enterprise Practice of Teachers in Vocational Colleges
}

\author{
Hong Zhang \\ School of Art and Design \\ Jiyuan Vocational and Technical College \\ Jiyuan, China 459000
}

\begin{abstract}
With the development of the comprehensive reform in the vocational education field, the practical ability of teachers in the vocational colleges becomes the main factor that restricts the quality of vocational education and the standard for the training of talents. At present, compared with the enterprises, the teachers in vocational college are more enthusiastic about the enterprise practice. The quality of the double-professionallytitled teachers is low. Effective ways to improve the enterprise practice of teachers in the vocational colleges are proposed, namely build the system for the enterprise practice, standardize the process and improve the evaluation system.
\end{abstract}

Keywords-vocational colleges; teachers; the enterprise practice

\section{INTRODUCTION}

The vocational education is an important part of the higher education and has cultivated numerous technical talents for the economic and social development. Under the background of the social and economic transformation, the higher vocational education meets unprecedented opportunities and challenges. The development direction and the historical mission of it change tremendously. With the development of the comprehensive reform in the vocational education field, the building of modern vocational education system, the innovation of school-running model and talent training model and the teaching reform become hot issues in the development of the vocational education. It is imperative for the teachers in the vocational colleges to improve the professional level and the practical ability. Participating in the enterprise practice is one of the effective ways to improve the practical ability of teachers.

\section{THE NECESSITY FOR TEACHERS IN THE VOCATIONAL COLLEGES TO PARTICIPATE IN THE ENTERPRISE PRACTICE}

The vocational education aims at training the technical talents with high quality, so the vocational colleges must have double-professionally-titled teachers who have high quality and professional skills. The construction of the teaching staff is the key to determine the teaching quality of the vocational colleges.

The participation of teachers in vocational college in the enterprise practice conforms to the direction of reform in the vocational education, the objective for the construction of teaching staff in the vocational colleges. It is an effective way to strengthen the cooperation between schools and enterprises and also the effective way to improve the quality of teachers of the vocational colleges. Different from the traditional "duckstuffing" type of teaching, the vocational education uses the teaching model with the involvement of the practice. The newtype teaching model breaks through the discipline frame and emphasizes taking the vocational ability as the training standard, taking the procedural knowledge as the content of the classroom teaching. At the meantime, it emphasizes the practical, applicable and frontier education, referring to the new perspective of the reform in the vocational education. In the process of the curriculum reform on the basis of the operation, the career experience, the practical ability, the enterprise background of teachers in the vocational colleges and the understanding of the teachers on the standard of post quality seem distinctly important. [1] Multiple national departments have introduced policies over the past ten years. It explicitly requires the schools to regularly dispatch the teachers to carry out the substituted post exercitation and take a temporary post, in order to improve the operational capacity and the practical level at the meantime to accumulate the work experience, build a reasonable knowledge system and provide guarantee for the classroom teaching.

The participation of teachers in the vocational college in the enterprise practice avails the establishment of a reasonable training system of vocational teachers and the improvement of the management system for teachers in the vocational colleges. At present, the vocational education in our country doesn't have the professional system to train teachers. It follows the training system for teachers in the traditional higher education. The system takes the degree training as the main contents. The majority of the vocational colleges adopt the model of bringing in talents from school to school. Most of the teachers in the vocational college directly enter the vocational colleges after graduation from general institutes of higher education. They lack the experience in the enterprise practice; although the objective of training double-professionally-titled teachers in the vocational colleges is explicit, the effects aren't obvious. The process of appraising and electing the doubleprofessionally-titled teachers is too simple. Schools neglect the quality requirements in the process of pursuing the quantity. Therefore, the participation of teachers in the vocational colleges in the enterprise practice can effectively make up for the deficiencies in the training system for teachers. It avails 
building the reasonable and scientific training system and then improves the quality of the double-professionally-titled teachers. Meanwhile, vocational colleges can build the system for teachers to participate in the enterprise practice, standardize the process related to the enterprise practice of teachers in the vocational colleges at the same time improve the quality of the participation of teachers in the enterprise practice, in order to promote the cultivation of the specialty leaders and the backbone teachers in the vocational colleges, adjust and improve the structure of the teaching staff in the vocational colleges and perfect the management system for teachers in the vocational colleges.

Participating in the enterprise practice will improve the professional quality of teachers. The participation of teachers in the vocational colleges is an important way to improve the practical teaching ability of teachers and enrich the working experience of teachers in the vocational colleges in the enterprise practice. In addition, it is a crucial way to construct the practical teaching staff with high ability and high level. Through participating in the enterprise practice, the teachers in the vocational colleges can not only thoroughly know about production process in the enterprise, but also effectively strengthen the professional knowledge system and the technical ability at the same time improve the accomplishment of enterprise culture of them; it promotes them to know about the latest and the frontier technology and the development direction, and helps them to understand and consolidate the professional technical knowledge and enriches the experience of teachers in the practical teaching. It expands the real teaching cases of teachers in the vocational colleges, broadens the professional horizon of them and meanwhile improves the consciousness of teachers in the vocational education. In addition, it helps teachers in the vocational colleges to establish the brand new concept of the vocational education in order to adapt to the social development. At the meantime, the teachers in the vocational colleges will become more pertinent in teaching. Therefore, organizing teachers to participate in the enterprise practice is an effective way to improve the practical skills and he professional quality of teachers in the vocational colleges. It also improves the scientific research ability and the innovation ability of teachers in the vocational colleges.

\section{CURRENT Situation OF TEACHERS IN THE VocATIONAL COLLEGES IN THE ENTERPRISE PRACTICE}

At present, the teachers in the vocational colleges universally have high academic qualifications, rich theoretical knowledge and poor operational ability but lack the practical experience. Considerable proportions of teachers fail to obtain the corresponding job qualification certificate and don't have experience in the enterprise practice. They cannot meet demands of the vocational education in teaching contents, teaching methods and means. Therefore, it's difficult for those teachers in the vocational colleges to train high-skilled talents who can adapt to the demands of the employment market and meet the job requirements. The critical shortage of the doubleprofessionally-titled teachers has become the biggest bottleneck for the sustainable development of the vocational education in our country. At the same time, it has severely restricted the sound development of the vocational education.
The quality of the double-professionally-titled teachers in the vocational colleges is low. Meanwhile, the teaching forms are inflexible. At the present stage, most of the vocational colleges come from the merger of the technical secondary schools and the technical schools. According to the background of teachers' training in the traditional higher education in our country, some teachers are the traditional teachers of the technical secondary schools and some are the graduates of ordinary institutions of higher learning. It directly leads to the situation that the teachers in the vocational colleges in our country at present lack the practice experience and the practical teaching experience. Moreover, they fail to attend the systematic training of the vocational education. The construction of the teaching staff does not conform to the development direction and the development speed of the vocational education. Therefore, the quality of the doubleprofessionally-titled teachers is not high. Some teachers are deeply influenced by the traditional teaching patterns of disciplines. They have an outdated educational concept and rigid teaching forms at the same time fail to update the teaching methods. It severely influences the teaching quality of the vocational education.

The vocational colleges attach importance to the enterprise practice, while the enterprises are not enthusiastic about it. In recent years, most of the vocational colleges have realized the importance of organizing the teachers to participate in the enterprise practice. They have taken measures to arouse the enthusiasm of teachers. The results indicate a big gap exists between the practice effect that the teachers in the vocational colleges participate in the enterprise practice and the expected effect. From the perspective of the vocational colleges, they have unsound systems including the examination and evaluation system. Besides, most of the systems are not operational; from the perspective of teachers, although participating in the enterprise practice, most of the teachers muddle through their work and fail to thoroughly know about the enterprises. What's more, the extra enterprise practice increases the burden of teachers; considering the economic benefit, majority of the enterprises are not willing to accept teachers to practice in the enterprises because they worry it will influence the normal productive results. Although some enterprises are willing to accept teachers, they refuse to provide important work for the teachers. The enterprises are not enthusiastic about it. Great limitations exist in many aspects. [2]

Varied practice patterns have advantages and disadvantages. On the whole, the vocational colleges have the following models for the enterprise practice of teachers. First, it is the autonomous model widely used by teachers at present. Teachers spend holidays and festivals and the spare time in participating in the enterprise practice. They are enthusiastic about it and have an explicit learning objective and an adequate learning motivation. In actual operation, certain gaps exist between the level of the teachers and the demands of the enterprises. The enthusiasm of the teachers and the indifference of the enterprises have contradictions. What's more, the time arrangement is random and the process management is loose, so the effects are unoptimistic. Second, it is the model driven by the projects of the enterprises. The 
teachers in the vocational colleges bring projects in the enterprises and solve the technological problems under the help of enterprise employees. Good results are achieved with joint efforts of the both sides, but the limitation is that the projects if teachers have few opportunities to conform to the development of the enterprises. Third, it is the masterapprentice model between the teachers and the experts of enterprises. The teachers in the vocational colleges learn from the experts of enterprises, in order to improve the practical ability. But this master-apprentice model cannot be popularized widely because many factors such as the specialty and the time are restricted.

\section{WAYS OF TEACHERS IN THE VOCATIONAL COLLEGES TO PARTICIPATE IN THE ENTERPRISE PRACTICE}

Envisaging and effectively solving the problems in the enterprise practice is the only way to improve effects of the enterprise practice. To participate in the enterprise practice, the premise is the active participation of the excellent enterprises; the guarantee is the fund investment and the encouragement policies of the government, especially the insight and the executive force of principal in the vocational colleges; and the fundamental is the autonomous participation of teachers in the vocational colleges.

The system of the enterprise practice for teachers in the vocational colleges must be built through many channels. A good public opinion environment is the foundation to achieve results. The vocational colleges can create the good public opinion environment for the enterprise practice and increase the publicity efforts, in order to let all sectors of society, including local governments at all levels, competent administrative departments for education at all levels, different vocational colleges, teachers and enterprises realize the significance of the enterprise practice in which the teachers in the vocational colleges participate; realize the significance of the enterprise practice in accelerating the construction of the teaching staff in the vocational colleges. At the meantime, they can realize its importance and particularity in the development of the vocational education, and pay high attention to the enterprise practice in which the teachers in the vocational colleges participate. Governments and competent administrative departments for education at all levels can cooperate via many ways and popularize policies and regulations of our country and the government on the enterprise practice participated by the teachers in the vocational colleges. They can analyze the significance of the enterprise practice of teachers in the vocational colleges on the development of the enterprises, in order to seek the best ways of cooperation.

Improve related laws and regulations. In terms of legislation, the government sectors at all levels are supported and encouraged to formulate the rules on cooperation between school and enterprise according to physical truth of local areas and introduce the corresponding rules related to the enterprise practice of teachers in the vocational colleges. Furthermore, they can improve relevant systems for teachers in the vocational colleges to participate in the enterprise practice. The competent administrative departments for education should take the initiative to assist the vocational colleges to raise funds, and actively promote the exchange and the coordination between vocational colleges and enterprises, as well as play the role of bridge, in order to provide helps for the teachers in the vocational colleges to participate in the enterprise practice; the vocational colleges should also think about in the long term, formulate the specific implementation methods and the longterm planning related to the system for the enterprise practice of teachers.

Establish the incentive systems for the enterprise practice of teachers in the vocational colleges. The vocational colleges combine the enterprise practice with the evaluation and the employment of professional and technical posts, and bring the enterprise practice in the performance assessment, in order to constantly encourage young teachers to devote to the enterprise practice. Meanwhile, they must formulate salary and job subsidies that conform to the assessment criterion related to the enterprise practice of teachers at the meantime combine the enterprise practice of teachers in the vocational colleges with the basic workload of teachers of the school.

The whole process of the enterprise practice for the teachers in the vocational colleges must be standardized. The vocational colleges formulate the systems matched with the enterprise practice of the teachers according to the objectives, the contents and the effects of the enterprise practice of teachers, and take corresponding management measures. Teachers formulate the practice schemes suitable for their specialty before the enterprise practice. Enterprises must formulate the practice schemes through consultation with schools and teachers according to the production requirements and the safety requirements of the enterprises before accepting the teachers. During the practice, teachers must have different practice contents and objectives at different stages. Enterprises arrange different posts and instructors and strictly manage. The practice tasks finished by the teachers must be checked by the instructors and must receive the management and the evaluation of enterprise employees. After the completion of practice, schools and employers evaluate the practice effects of teachers in the vocational colleges.

Improve the examination and evaluation system for the enterprise practice of teachers in the vocational colleges. The establishment of the examination and evaluation system for the enterprise practice must execute through following the scientific, guided and incentive principle. Meanwhile, it must follow the development rules of teachers and the characteristics of the vocational education, truly, correctly and roundly reflect the process and the result of the enterprise practice and constantly arouse teachers' enthusiasm in the practice. The contents of teachers' practice are important in the system. The formulation of the system must conform to the characteristics of different disciplines; because the teachers in the vocational colleges have different professional and technical posts and grades, the examination and evaluation system must be different, so are the contents and evaluation standards; because ways of teachers to participate in enterprise practice are different, the standards of the evaluation system must be different.

The examination and evaluation system for the enterprise practice of teachers in the vocational colleges must include job 
content, working attitude, attendance, task implementation, professional application, research and development of new technology, technology service, the participation in specialty construction and practice results. The forms of evaluation system include the combination between school and enterprise, between objective assessment and process assessment, between self-assessment and others' assessment.

\section{CONCLUSION}

The participation of teachers in the vocational colleges in the enterprise practice conforms to the characteristics and the development direction of the vocational education, avails teachers' development and improves the educational quality of vocational colleges. Meanwhile, it improves the level of labor productivity and contributes to the sound economic and social development. Participating in the enterprise practice is the main way for the improvement of vocational college teachers. They must take the initiative to participate and constantly improve the practical ability and the professional quality.

\section{REFERENCES}

[1] Chen Qiaohui. Analysis on Problems of Vocational Teachers' Enterprise Practice and Countermeasures [J], Innovation Education, the $31^{\text {st }}$ Issue in 2012

[2] Bian Hua. Research on Standardization of Evaluation and Management of Higher Vocational College Teachers' Enterprise Practice [J], Journal of Chengdu Aeronautic Polytechnic, September 2013 